Volume 1, Number 2, 2015

\title{
Simplified Method for Calculation of the Joule-Thomson Coefficient at Natural Gas Flowrate Measurement
}

\author{
Yevhen Pistun, Fedir Matiko ${ }^{*}$, Oleh Masnyak \\ Lviv Polytechnic National University, 12. S. Bandery St., Lviv, 79013, Ukraine
}

Received: October 09, 2015. Revised: November 24, 2015. Accepted: December 08, 2015.

(C) 2015 The Authors. Published by Lviv Polytechnic National University.

\begin{abstract}
This work deals with measurement of natural gas flowrate and volume by means of pressure differential devices. The existing methods for calculation of Joule-Thomson coefficient to be applied in pressure differential flowmeters are analyzed in the paper. A new method which uses a simplified set of parameters of gas composition, namely the density at standard conditions, the molar content of nitrogen and carbon dioxide, is developed by the authors. This method provides the possibility to calculate the Joule-Thomson coefficient within the pressure range from $0.1 \mathrm{MPa}$ to 15.0 MPa and the temperature range from $250 \mathrm{~K}$ to $350 \mathrm{~K}$. It was defined that for natural gas with density at standard conditions up to $0.75 \mathrm{~kg} / \mathrm{m}^{3}$ and contents of nitrogen and carbon dioxide up to $5 \%$ of each component, the relative error of the values derived according to the new developed method do not exceed $3.0 \%$ in the specified ranges of temperature and pressure. The application of this method in calculators of flowrate and volume of natural gas will help to reduce the systematic error of flowrate and volume measurement caused by the distinction of gas temperature in the place of measurement downstream of primary device from gas temperature upstream of primary device.
\end{abstract}

Keywords: Joule-Thomson coefficient; natural gas; methods for calculation; pressure differential flowmeters; systematic error.

\section{Introduction}

The pressure differential flowmeters are used for the measurement of natural gas flowrate and volume in largediameter pipelines. The application of this method is regulated by national standards based on ISO 5167:2003 [1]. According to ISO 5167:2003 [1], it is possible to take into account the systematic error of gas flowrate measurement caused by distinction of gas temperature in the place of measurement downstream of primary device (PD) from gas temperature upstream of PD. Gas temperature measured downstream of PD has to be corrected if "... high accuracy of flowrate measurement is required and there are considerable pressure losses at the primary device" [1].

The main problem at application of such a correction has been absence of a simple method for the determination of gas temperature by calculating Joule-Thomson coefficient. A simplified equation for calculating this coefficient is proposed in the standard ISO/TR 9464 [2] but its accuracy is not high. Deviations of values calculated by the equation [2] from the values obtained using [3] are up to $10 \%$ for natural gas with typical composition. The main reason for this is that the equation [2] does not take into account changes of the gas composition. Therefore, development of method for calculation of Joule-Thomson coefficient using a simplified set of parameters for natural gas is a very important problem.

\section{Analysis of the existing methods}

As is well known, the flow of gas through the PD is accompanied by variation of the state parameters of the gas (pressure, temperature and density) along the measuring part of the pipeline. Variation of gas temperature in vena contracta and downstream of PD leads to the fact that the gas flow temperature in the place of PD is different from the

* Corresponding author. Email address: fmatiko@gmail.com 
gas flow temperature in the place of temperature transmitter installed at a distance of $5 \ldots 15$ pipe internal diameters downstream of PD [1]. It is impossible to measure the gas temperature immediately upstream of PD, as it is required by the theory of the pressure differential method, without distortion of the kinematic structure of the flow. Hence, according to [1] the gas temperature difference intermediately upstream of PD and in the place of the thermometer is calculated as

$$
\Delta T=\mu_{J T} \cdot \Delta \omega,
$$

where $\mu_{J T}$ is Joule-Thomson coefficient; $\Delta \omega$ is pressure loss across primary device.

In order to use the equation (1), it is necessary to know Joule-Thomson coefficient which depends on pressure, temperature and composition of natural gas.

The Joule-Thomson coefficient can be determined by using one of the equations where this coefficient depends on the parameters of the gas state. The form of this equation depends on the type of equation of state being applied.

The existing standards [4-6] provide the equation of state of natural gas as a function of the compressibility factor $Z$, of the density $\rho$ and temperature $T$ in order to describe the condition of natural gas. In this case the equation for calculating $\mu_{J T}$ coefficient can be written as follows [7]

$$
\mu_{J T}=\left[T\left(\frac{\partial Z}{\partial T}\right)_{\rho}-\rho\left(\frac{\partial Z}{\partial \rho}\right)_{T}\right] /\left[c_{p} \rho\left(z+\rho\left(\frac{\partial Z}{\partial \rho}\right)_{T}\right)\right] \text {, }
$$

where $T$ is gas temperature; $Z$ is gas compressibility factor; $\rho$ is gas density at operating conditions; $c_{p}$ is gas isobaric heat capacity at operating conditions.

Using the formula (2) and the VNIC SMV equation of state [4] (equation developed by Russian Research Center for Standardization of Materials and Substances), we obtained the following equation

$$
\mu_{J T}=10^{3}\left(A_{2}-A_{1}\right) /\left(c_{p} \rho\left(1+A_{1}\right)\right) .
$$

The values of dimensionless coefficients A1, A2 are calculated in accordance with [4]

The equation (3) can be used for calculating the Joule-Thomson coefficient in the scope of VNIC SMV equation (gas pressure is less than $12 \mathrm{MPa}$, gas temperature is from 250 to $340 \mathrm{~K}$ ) when the complete gas composition is known.

The fundamental equation which relates the Helmholtz free energy to the reduced density, temperature and composition of the gas is presented in the international standard [3]. The equations for determination of thermodynamic properties including Joule-Thomson coefficient are presented in [3] and are obtained on the basis of the equations of partial derivatives of the Helmholtz free energy. The method proposed in [3] is used for the calculation of properties of gas mixtures and has a wide application area ( $p \leq 30 \mathrm{MPa}, 250 \leq T \leq 350 \mathrm{~K})$.

The methods based on the equations of state using the data on gas composition (VNIC SMV [4] method in particular) and the method proposed in [3] have some shortcomings in terms of application in flowmeters. All of them are based on the equations with interrelated parameters $(Z, \rho)$ and $(p, \rho)$. These parameters can be calculated only by iteration which increases the loading of the processors in the calculators of gas flowrate. The methods require the data about the complete composition of the gas which causes the need for the correction of software of existing calculators most of which use simplified data about the gas composition.

The curves of Joule-Thomson coefficient versus gas pressure at fixed temperatures are shown on Figure 1. They are calculated by the equations from [3] for natural gas with a molar content of nitrogen of $0.997 \%$ and of carbon dioxide of $0.612 \%$ and with the density at standard conditions of $0.701 \mathrm{~kg} / \mathrm{m}^{3}$ within the pressure range from 0.1 to $15 \mathrm{MPa}$ and temperature range from 250 to $350 \mathrm{~K}$. These ranges of pressure and temperature meet the needs of natural gas metering during its extraction, transmission and distribution. 


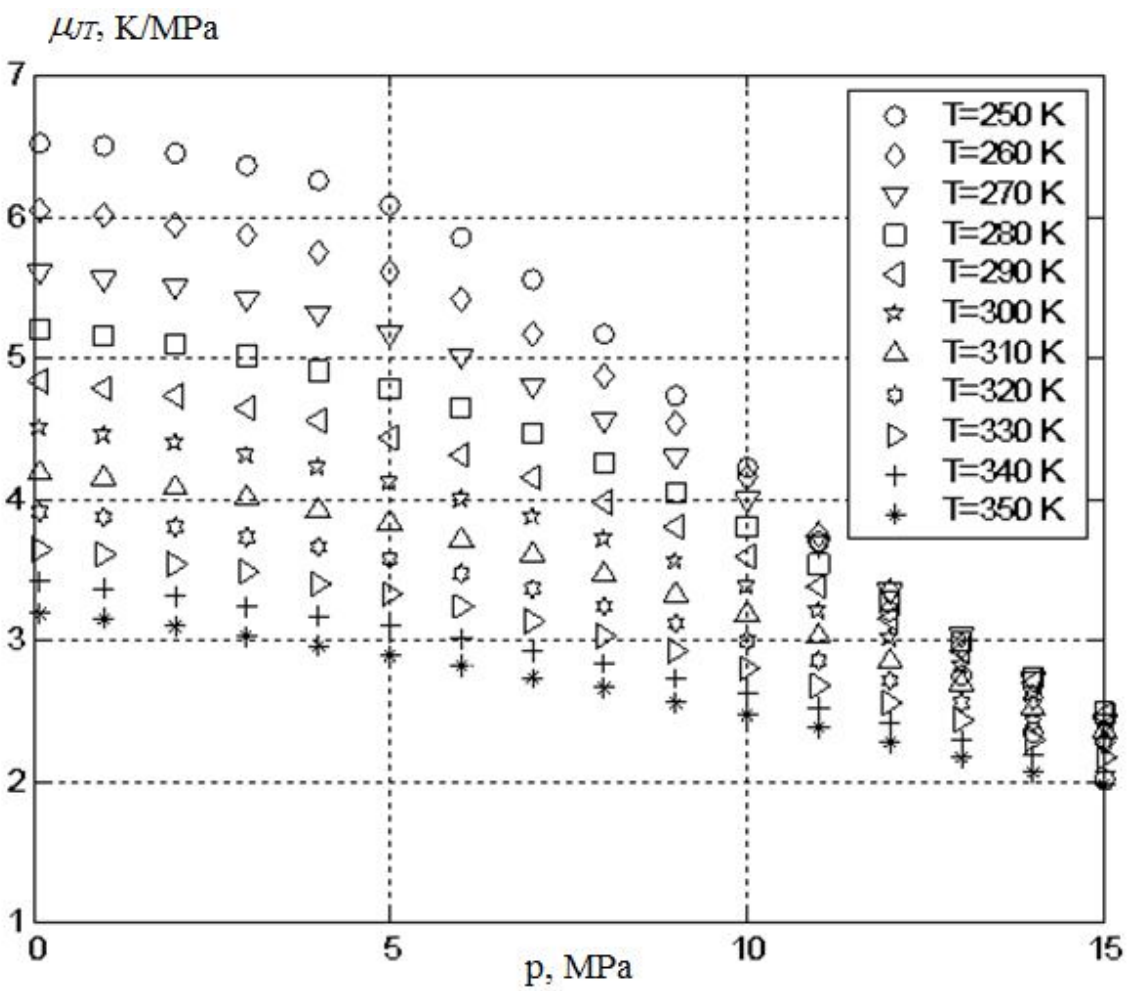

Fig. 1. Joule-Thomson coefficient versus gas pressure for various temperatures

The figure shows that the coefficient $\mu_{J T}$ has the maximum value at low pressure and temperature. Sensitivity of the coefficient $\mu_{J T}$ to temperature variations increases with decreasing pressure. Contrariwise the Joule-Thomson coefficient and its sensitivity to temperature variations significantly decrease at high pressure $(p>10 \mathrm{MPa})$. The Joule-Thomson coefficient $\mu_{J T}$ is close to the maximum at gas pressure below $5 \mathrm{MPa}$ which covers the area where most of pressure differential flowmeters operate. Therefore, it is very important to consider the throttling processes in this range of pressure.

\section{New method for calculation of the Joule-Thomson coefficient}

A new method for calculating the Joule-Thomson coefficient within the pressure range from 0.1 to $15 \mathrm{MPa}$ and temperature range from 250 to $350 \mathrm{~K}$ was developed by us. This method uses a simplified set of parameters of gas composition namely the density at standard conditions, the molar content of nitrogen and carbon dioxide.

The method is developed using the principle of corresponding states. Its basic equation describes the dependence of the Joule-Thomson coefficient on the reduced temperature and density. The coefficients of the basic equation are obtained by processing the values $\mu_{J T}$ calculated using [3] within the pressure range from 0.1 to $15 \mathrm{MPa}$ and the temperature range from 250 to $350 \mathrm{~K}$. According to the method the Joule-Thomson coefficient is calculated as follows

$$
\mu_{J T}=\sum_{i=1}^{6} \sum_{j=1}^{5} a_{i j} \tau^{5-j} \omega^{6-i} .
$$

The values of coefficients $a_{i j}$ are given in the Table 1 .

The reduced temperature $\tau$ and density $\omega$ are calculated as

$$
\begin{aligned}
& \tau=T / T_{p c}, \\
& \omega=\rho / \rho_{p c} .
\end{aligned}
$$


The density of gas at operating conditions can be calculated as follows

$$
\rho=p T_{s c} \rho_{s c} /\left(p_{s c} T K\right)
$$

Table 1. Coefficients $a_{i j}$ in equation (4)

\begin{tabular}{|c|c|c|c|c|c|}
\hline \multirow{2}{*}{$i$} & \multicolumn{5}{|c|}{$j$} \\
\cline { 2 - 6 } & 1 & 2 & 3 & 4 & 5 \\
\hline \hline 1 & -67.802 & 446.76 & -1102.4 & 1209.1 & -498.87 \\
\hline 2 & 143.8 & -965.14 & 2433.4 & -2736.8 & 1162.1 \\
\hline 3 & -113.04 & 775.41 & -2001.9 & 2307.9 & -1003.15 \\
\hline 4 & 22.27 & -158.22 & 420 & -490.79 & 209.56 \\
\hline 5 & 14.178 & -95.204 & 241.87 & -276.03 & 118.25 \\
\hline 6 & 2.7783 & -20.996 & 62.704 & -90.622 & 56.442 \\
\hline
\end{tabular}

The compressibility factor $K$ for the simplified data about gas composition and pressure below 12 MPa can be calculated according to methods NX19 mod., GERG91 mod. [4] and SD 7-2005 [8], and at pressure above 12 MPa only methods in [8] can be used.

The pseudocritical temperature of gas is calculated by the formula [4]

$$
T_{p c}=88.25 \cdot\left(0.9915+1.759 \cdot \rho_{s c}-1.681 \cdot x_{N 2}-x_{C O 2}\right) .
$$

The pseudocritical density of gas is calculated by the simplified formula developed by the authors

$$
\rho_{p c}=163.5 \cdot\left(\rho_{s c} / 0.6682\right)^{0.6}+62.62 \cdot x_{N 2}+163.359 \cdot x_{C O 2} \text {. }
$$

\section{Verification of the developed method}

Verification of the developed method has been made for natural gas compositions according to the quality certificates from laboratories of gas transmission companies in Ukraine. The reference values of $\mu_{J T}$ were calculated using the equations [3]. The relative deviations of the results for the developed method do not exceed $1.5 \%$ for the typical natural gas compositions (see Table 2). The maximum deviation $\delta_{M_{-} \max }$ for the method proposed by the authors and the maximum deviation $\delta_{T R_{-} \max }$ for the equation from the ISO/TR 9464 [2] are calculated as

$$
\delta=\max \left(100 \cdot\left|\mu_{J T i}-\mu_{J T[3] i}\right| / \mu_{J T[3] i}\right) .
$$

Based on the detailed analysis, it was defined that for natural gas with density at standard conditions up to $0.75 \mathrm{~kg} / \mathrm{m}^{3}$ and contents of nitrogen and carbon dioxide up to $5 \%$ of each component, the relative deviations of the

\begin{tabular}{|c|c|c|c|c|c|c|c|c|c|c|}
\hline \multirow{2}{*}{ \# } & \multicolumn{7}{|c|}{ Gas composition } & \multirow{2}{*}{$\begin{array}{c}\rho s c, \\
\mathrm{~kg} / \mathrm{m}^{3}\end{array}$} & \multirow{2}{*}{$\delta_{M-\max }}$, & \multirow{2}{*}{$\begin{array}{c}\delta_{T R_{\max }}, \\
\quad \%\end{array}$} \\
\hline & Methane & Ethane & Propane & Butane & Iso-butane & N2 & $\mathrm{CO} 2$ & & & \\
\hline 1 & 98.21 & 0.628 & 0.214 & 0.108 & 0.0 & 0.80 & 0.04 & 0.6807 & 0.98 & 10.35 \\
\hline 2 & 97.841 & 0.914 & 0.248 & 0.042 & 0.065 & 0.850 & 0.04 & 0.6830 & 1.05 & 9.84 \\
\hline 3 & 96.961 & 1.345 & 0.383 & 0.130 & 0.0 & 1.018 & 0.163 & 0.6898 & 0.99 & 8.78 \\
\hline 4 & 96.046 & 1.844 & 0.524 & 0.082 & 0.063 & 0.952 & 0.489 & 0.6981 & 0.80 & 7.27 \\
\hline 5 & 92.82 & 2.490 & 0.701 & 0.107 & 0.075 & 1.083 & 0.724 & 0.7080 & 0.67 & 5.67 \\
\hline 6 & 93.635 & 3.075 & 0.881 & 0.141 & 0.170 & 1.181 & 0.917 & 0.7186 & 0.47 & 3.85 \\
\hline 7 & 90.70 & 4.5 & 0.84 & 0.22 & 0.10 & 3.14 & 0.5 & 0.7320 & 1.3 & 3.45 \\
\hline
\end{tabular}
values derived according to the developed method from the values derived according to [3] do not exceed $3.0 \%$ in the specified ranges of temperature and pressure.

Table 2. Results of verification of simplified method for calculation of the Joule-Thomson coefficient 
The example of calculation of the systematic error $\delta_{\text {syst }}$ of natural gas flowrate measurement for the flowmeter which operates at differential pressure of $\Delta p=100 \mathrm{kPa}$ and various values of diameter ratio b of orifice plate is shown in Table. 3. The parameters of flowmeter presented in the example meet the requirements of the standards [1].

As it is shown in Table 3, the systematic error of measurement of gas flowrate caused by lowering the gas temperature during gas throttling through PD can reach $0.1 \%$ for the flowmeters which meet the requirements at [1]. Therefore, it is very important to eliminate such a large systematic measurement error of gas flowrate.

Table 3. The example of calculation of the systematic error $\delta_{\text {syst }}$

\begin{tabular}{|c|c|c|c|}
\hline \multicolumn{4}{|l|}{ Input data } \\
\hline Absolute pressure of gas upstream of PD & \multicolumn{3}{|c|}{$p_{1}=0.5 \mathrm{MPa}$} \\
\hline Temperature of gas downstream of PD & \multicolumn{3}{|c|}{$T_{2}=273.15 \mathrm{~K}$} \\
\hline Differential pressure across PD & \multicolumn{3}{|c|}{$\Delta p=100 \mathrm{kPa}$} \\
\hline Density of gas at standard conditions & \multicolumn{3}{|c|}{$\rho_{\mathrm{sc}}=0.7186 \mathrm{~kg} / \mathrm{m}^{3}$} \\
\hline Nitrogen content & \multicolumn{3}{|c|}{$x_{\mathrm{N} 2}=0.01181$ (molar part) } \\
\hline Carbon dioxide content & \multicolumn{3}{|c|}{$x_{\mathrm{CO} 2}=0.00917$ (molar part) } \\
\hline \multicolumn{4}{|c|}{ Results of calculation } \\
\hline Joule-Thomson coefficient & \multicolumn{3}{|c|}{$\mu_{J T}=5.59 \mathrm{~K} / \mathrm{MPa}$} \\
\hline Diameter ratio of orifice plate $\beta$ & 0.2 & 0.4 & 0.6 \\
\hline Pressure loss across the PD $\Delta \omega, \mathrm{kPa}$ & 95.3 & 82.5 & 62.1 \\
\hline $\begin{array}{l}\text { Variation of gas temperature because of the throttling at the orifice plate } \\
\Delta T=\mu_{J T} \cdot \Delta \omega, \mathrm{K}\end{array}$ & 0.53 & 0.46 & 0.35 \\
\hline $\begin{array}{l}\text { Temperature of gas upstream of the orifice plate } \\
T_{1}=T_{2}+\Delta T, \mathrm{~K}\end{array}$ & 273.68 & 273.61 & 273.5 \\
\hline $\begin{array}{l}\text { Relative deviation of gas flowrate at temperature variation of } \Delta T, \\
\delta_{\text {syst }}=100\left(Q_{T 2}-Q_{T 1}\right) / Q_{T 1}, \%\end{array}$ & 0.100 & 0.087 & 0.065 \\
\hline
\end{tabular}

\section{Conclusions}

The Joule-Thomson coefficient at natural gas metering (when the complete composition of gas is known) can be calculated according to formula (2) and equations of state [4-6] or according to the equations in [3]. The simplified method [2] and method for calculating the Joule-Thomson coefficient proposed in this paper is much more convenient for application in the gas flow calculators. This method provides the possibility to calculate the Joule-Thomson coefficient using the simplified data about the gas composition within the pressure range from $0.1 \mathrm{MPa}$ to $15.0 \mathrm{MPa}$ and the temperature range from $250 \mathrm{~K}$ to $350 \mathrm{~K}$.

The application of this method in flow calculators of natural gas will provide higher accuracy of calculation of the Joule-Thomson coefficient in comparison to the equation [2] and will help to reduce the systematic error of measurement of gas flowrate caused by the distinction of gas temperature in the place of measurement downstream of PD from gas temperature upstream of PD.

\section{References}

[1] ISO 5167.1-4:2003. Measurement of fluid flow by means of pressure differential devices inserted in circular cross-section conduits running full.

[2] ISO/TR 9464. Guidelines for the use of ISO 5167:2003.

[3] ISO 20765-1:2005. Natural gas - Calculation of thermodynamic properties. Pt. 1: Gas phase properties for transmission and distribution applications.

[4] GOST 30319.0:3-96. Natural gas. Methods of calculation of physical properties.

[5] ISO 12213-2. Natural gas - Calculation of compression factor. Part 2: Calculation using molar-composition analysis.

[6] ISO 12213-3. Natural gas - Calculation of compression factor. Part 3: Calculation using physical properties.

[7] E. Shpilrain, P. Kesselman. Foundations of the thermophysical properties of substances. Moscow, Publishing House "Energiya”, 1977.

[8] SD 7-2005. Natural gas. Methods of calculation of compressibility factor within the pressure range from 12 to $25 \mathrm{MPa}$. (in Russian) 


\title{
Спрощений метод розрахунку коефіцієнта Джоуля-Томсона під час вимірювання витрати природного газу
}

\author{
Євген Пістун, Федір Матіко, Олег Масняк \\ Національний університет “Львівська політехніка”, вул. С. Бандери, 12, м. Львів, 79013, Україна
}

\begin{abstract}
Анотація
Подано аналіз існуючих методів розрахунку коефіцієнта Джоуля-Томсона, за результатами якого встановлено необхідність розроблення методу розрахунку на основі спрощеного набору параметрів складу газу. Представлено новий метод для розрахунку коефіцієнта Джоуля-Томсона у діапазоні абсолютного тиску газу від 0,1 МПа до 15 МПа та температури від 250 К до 350 К. Основне рівняння методу побудоване на основі принципу відповідних станів і описує залежність коефіцієнта Джоуля-Томсона від приведених температури та густини. Для обчислення приведеної густини газу запропоновано застосовувати розроблене авторами рівняння псевдокритичної густини природного газу. Виконано детальне тестування розробленого

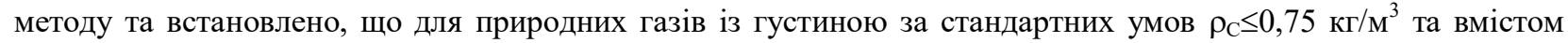
азоту і вуглекислого газу до 5 \% кожного, відносне відхилення значень методу від розрахункових значень коефіцієнта Джоуля-Томсона, отриманих за методом ISO 20765-1, не перевищує $\pm 3,0 \%$ для вказаних діапазонів тиску та температури газу. Наведено приклади розрахунку систематичної похибки вимірювання витрати за допомогою витратоміра змінного перепаду тиску, зумовленої ефектом Джоуля-Томсона.
\end{abstract}

Ключові слова: коефіцієнт Джоуля-Томсона; природний газ; метод розрахунку; витратомір змінного перепаду тиску; систематична похибка. 